\title{
Workplace violence against security personnel at a university hospital in Egypt: a cross-sectional study [version 1; peer
}

\section{review: 2 approved]}

\author{
Ahmed A. Albadry (D1, Abdel-Hady El-Gilany², Hala Samir Abou-EIWafa \\ ${ }^{1}$ Industrial Medicine and Occupational Health, Public Health \& Community Medicine Department, Faculty of Medicine, Mansoura \\ University, Mansoura, Egypt \\ ${ }^{2}$ Public Health and Preventive Medicine, Public Health and Community Medicine Department, Faculty of Medicine, Mansoura \\ University, Mansoura, Egypt
}

V1 First published: 11 May 2020, 9:347

https://doi.org/10.12688/f1000research.23252.1

Latest published: 11 May 2020, 9:347

https://doi.org/10.12688/f1000research.23252.1

\section{Abstract}

Background: Violence is common among security personnel. To the best of the authors' knowledge no recent studies have investigated this problem. This study aimed to estimate the prevalence and associated factors of violence against hospital security personnel and describe circumstances of violence, type of perpetrators, and victims' response.

Methods: In total, 170 security personnel from a university hospital in Egypt were recruited in this cross-sectional study. Data were collected using the Arabic version of a questionnaire developed by the International Labour Office.

Results: The majority (87.3\%) of security personnel reported violence exposure in the past year. Being a woman and working more than 5 years were independent predictors of violence exposure. The commonest forms of physical violence were pushing and beating. Verbal abuse and threats were the commonest emotional violence. Patients and their relatives/friends were the commonest perpetrators of violence.

Conclusions: Violence is common among hospital security personnel in this setting. Adequate training and recruitment of more security personnel may contribute to decreasing violence.

Keywords

Hospital violence, Security personnel, occupational exposure

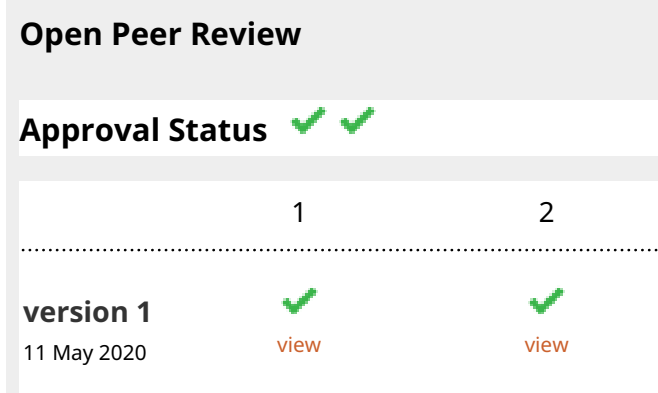

1. Ibrahim Kabbash (D), Tanta University,

Tanta, Egypt

2. Amal A. Hegazy (iD), King Abdulaziz

University, Jeddah, Saudi Arabia

Al-Azhar University, Cairo, Egypt

Any reports and responses or comments on the article can be found at the end of the article.

This article is included in the Sociology of

Health gateway. 
Corresponding author: Ahmed A. Albadry (albadry@live.com)

Author roles: Albadry AA: Conceptualization, Formal Analysis, Investigation, Methodology, Project Administration, Resources, Writing Original Draft Preparation; El-Gilany AH: Investigation, Methodology, Project Administration, Resources, Supervision, Validation, Visualization; Abou-EIWafa HS: Conceptualization, Data Curation, Formal Analysis, Methodology, Resources, Validation, Visualization, Writing - Review \& Editing

Competing interests: No competing interests were disclosed.

Grant information: The author(s) declared that no grants were involved in supporting this work.

Copyright: (c) 2020 Albadry AA et al. This is an open access article distributed under the terms of the Creative Commons Attribution License, which permits unrestricted use, distribution, and reproduction in any medium, provided the original work is properly cited.

How to cite this article: Albadry AA, El-Gilany AH and Abou-ElWafa HS. Workplace violence against security personnel at a university hospital in Egypt: a cross-sectional study [version 1; peer review: 2 approved] F1000Research 2020, 9:347 https://doi.org/10.12688/f1000research.23252.1

First published: 11 May 2020, 9:347 https://doi.org/10.12688/f1000research.23252.1 


\section{Introduction}

Workplace violence (WPV) is well-defined as any act or danger of physical violence, harassment, bullying, or other disruptive activities at the workplace that may result in physical or emotional problems ${ }^{1}$. The literature and news show that violence is common globally and occurs every day in various public spheres, including the health system ${ }^{2}$.

Healthcare violence reflects violence in society in general. However, violence contradictory to social expectations that hospitals are sites that denote security, care, sympathy, and lifesaving. It is hard to acknowledge that violent incidents occur commonly in hospitals and in some situations physical violence in hospitals can be exceedingly dangerous ${ }^{3}$.

Healthcare WPV is an underestimated and constant problem that has been widely overlooked. Many healthcare organizations and institutions that are considered safe resorts are now facing "steadily growing rates of crime, including violent criminalities such as stabbing, rape, and homicide" as stated by Phillips ${ }^{4}$. According to the US Agency of Labor Statistics 2007 report, violence occurs more habitually in healthcare and social support organizations than in any other labor force segment and is responsible for $60 \%$ of all nonfatal assaults within this segment ${ }^{5}$.

The majority of research studies have revealed that following an incident of WPV, there are high rates of lost working days, burnout, and dissatisfaction, in addition to decreased feelings of wellbeing among staff members ${ }^{6,7}$. In return, fright at work has even driven some healthcare personnel to protect themselves by carrying weapons, mostly firearms or knives ${ }^{8}$.

Hospital security officers are required to protect the safety of healthcare workers, hospital guests, and patients. They are asked to assist in control of violent situations and are consequently at an elevated risk to tolerate violence-associated incidences and are therefore recognized as a group at high risk of being attacked ${ }^{9}$. They are often disregarded in the literature concerning healthcare violence-related incidences. The comparatively few studies that do involve hospital security staff demonstrate that these workers are among groups with the highest rates of violence-related incidences within the healthcare setting $^{10-12}$.

The significance of policies and security staff training has been accepted and various hospitals offer limitation tools and weapons to security personnel. Such establishment, chiefly of non-lethal intermediary weapons (e.g. conducted electrical weapons) or lethal weapons (e.g. handguns) has been conflicted owing to the moral, legal, and financial issues related to the well-being and safety of patients and staff in hospitals ${ }^{13,14}$.

WPV directed towards hospital security staff has seldom been studied in developing countries including Egypt; thus, the actual magnitude of the problem is unknown. The purposes of this study are to estimate the prevalence and associated issues of different types of violence against hospital security personnel, conditions of violence, category of perpetrators, and victims' reaction in a university hospital setting.

\section{Methods}

Study description and participants

This descriptive cross-sectional study was conducted among formal security personnel at a university hospital from September 1, 2018 to October 31, 2018.

All formal security personnel were the target population. The inclusion criteria were permanent or temporary workers employed for 1 year or more.

Approval for the study was obtained from the Institutional Research Board at the university hospital (proposal number: R.18.07.236). The name of the university hospital has been blinded to protect anonymity of participants. Written informed consent of study participants to participate willingly in the study with the right to withdraw from the research at any time was obtained with a guarantee of confidentiality and anonymity of the information.

\section{Data collection}

Workers fulfilling the eligibility criteria were interviewed at their workplace at the beginning of the workday before their work shift after arrangement with their direct supervisor in the supervisor room. The English version of the questionnaire developed by the International Labor Office, International Council of Nurses, World Health Organization, and Public Services International (2003) regarding WPV in the health sector was used in Arabic (English version available here: https://www. who.int/violence_injury_prevention/violence/interpersonal/en/ WVquestionnaire.pdf. A modified Arabic version of this questionnaire was developed and tested for validity and reliability in a previous study in Saudi Arabia ${ }^{15}$. The questionnaire was used to collect the following information: demographics and workplace characteristics; WPV in the past year; its nature, frequency, response, consequences, and satisfaction of incident handling; policies, and strategies to deal with the incident.

\section{Data analysis}

Data were statistically analysed using the Statistical Package for Social Sciences (SPSS) version 20. Data were presented in the form of numbers and \%. Chi-squared test was used to determine significant risk factors of violence. Multivariate logistic regression analysis using forward Wald method was run to identify significant independent predictors of violence. Crude and adjusted odds ratios and their $95 \%$ confidence intervals were considered. $\mathrm{P} \leq 0.05$ was considered statistically significant.

\section{Results}

The questionnaire was completed by 150 out of 170 legible security personnel (response rate $88.2 \%$ ) who reported a total number of 553 workplace events in the past year.

The majority $(87.3 \%)$ of security personnel reported exposure to violence in the past year. Being a woman and working for over 5 years were independent predictors of violence exposure (adjusted odds ratio $(\mathrm{AOR})=7.7$ and 10.1, respectively; Table 1).

Table 2 shows that the commonest suggestions from participants to prevent violence were training (73.3\%) and assigning 


\section{Table 1. Prevalence of workplace violence against security personnel at a university hospital in Egypt and its predictors during past year.}

\begin{tabular}{|l|l|l|l|l|}
\hline & Total, $\mathbf{n}$ & $\begin{array}{l}\text { Violence } \\
\text { experienced, } \\
\mathbf{n}(\mathbf{\%})\end{array}$ & $\begin{array}{l}\text { Crude odds } \\
\text { ratio (95\%) }\end{array}$ & $\begin{array}{l}\text { Adjusted odds } \\
\text { ratio (95\%) }\end{array}$ \\
\hline Total & 150 & $131(87.3)$ & $(82.0-92.7)$ & \\
\hline $\begin{array}{l}\text { Gender } \\
\text { Male }\end{array}$ & 94 & $77(81.9)$ & $1(r)$ & $1(r)$ \\
\hline $\begin{array}{l}\text { Female } \\
\text { Age, years }\end{array}$ & 56 & $54(96.4)$ & $6.0(1.3-26.9)^{* *}$ & $7.7(1.6-336.3)^{* *}$ \\
\hline $\begin{array}{l}<5 \\
\geq 35\end{array}$ & 93 & $75(80.6)$ & $1(r)$ & \\
\hline $\begin{array}{l}\text { Duration of work, years } \\
1-5\end{array}$ & 57 & $56(98.2)$ & $13.4(1.7-103.7)^{\star *}$ & \\
\hline$>5$ & 67 & $51(76.1)$ & $1(r)$ & $1(r)$ \\
\hline $\begin{array}{l}\text { Previous training } \\
\text { No } \\
\text { Yes }\end{array}$ & 83 & $80(96.4)$ & $8.4(2.3-30.2)^{* * *}$ & $10.1(2.7-37.4)^{* * *}$ \\
\hline $\begin{array}{l}\text { Constant } \\
\text { Model } \chi 2 \\
\% \text { correctly predicted }\end{array}$ & 68 & $57(83.8)$ & $1(r)$ & \\
\hline
\end{tabular}

$r=$ reference group. ${ }^{* *} \mathrm{P} \leq 0.01{ }^{* * *} \mathrm{P} \leq 0.001$

\begin{tabular}{|c|c|c|c|}
\hline \multirow{2}{*}{ Measure to prevent violence } & Won't help & $\begin{array}{l}\text { Will help to } \\
\text { some extent }\end{array}$ & Will help \\
\hline & \multicolumn{3}{|l|}{ n (\%) } \\
\hline Train workers on how to prevent violence. & $15(10.0)$ & $25(16.7)$ & $110(73.3)$ \\
\hline Assign large numbers of security personnel over different work shifts. & $15(10.0)$ & $41(27.3)$ & $94(62.7)$ \\
\hline Create a commission responsible for protection of employees in the course of duty. & $22(14.7)$ & $41(27.3)$ & $87(58.0)$ \\
\hline Change work environment and flow. & $16(10.7)$ & $48(32.0)$ & $86(57.3)$ \\
\hline $\begin{array}{l}\text { Familiarize employees with their legal rights if they are subjected to violence in their } \\
\text { workplace. }\end{array}$ & $23(15.3)$ & $42(28.0)$ & $85(56.7)$ \\
\hline Define prohibitions within procedures for admission of patients. & $26(17.3)$ & $39(26.0)$ & $85(56.7)$ \\
\hline Create a policy for care of violence victims. & $23(15.3)$ & $43(28.7)$ & $84(56.0)$ \\
\hline Install violence alarm system. & $36(24.0)$ & $33(22.0)$ & $81(54.0)$ \\
\hline $\begin{array}{l}\text { Introduce a practical procedure for how to deal with the reality of violence that } \\
\text { occurs in the workplace. }\end{array}$ & $41(27.3)$ & $31(20.7)$ & $78(52.0)$ \\
\hline Install metal detectors at all entrances. & $44(29.3)$ & $31(20.7)$ & $75(50.0)$ \\
\hline Improve the level of lighting in all sections of the health facility. & $33(22.0)$ & $43(28.7)$ & $74(49.3)$ \\
\hline Use the closed-circuit television system. & $51(34.0)$ & $32(21.3)$ & $67(44.6)$ \\
\hline $\begin{array}{l}\text { Create a guide to each section of the health facility that determines the different } \\
\text { forms of violence against workers and how to deal with this. }\end{array}$ & $30(20.0)$ & $58(38.7)$ & $62(41.3)$ \\
\hline Other administrative measures. & $36(24.0)$ & $56(37.3)$ & $58(38.7)$ \\
\hline
\end{tabular}


a large number of personnel $(62.7 \%)$, while Table 3 shows that the commonest forms of physical violence reported by personnel were pushing (24.8\%), beating (18.6\%) and throwing objects $(12.3 \%)$. The threat of physical force and verbal abuse were the commonest emotional violence experienced by participants (23.7\% and 20.4\%; respectively). Patients' relatives/ friends and patients themselves were the commonest perpetrators of violent events ( $72.5 \%$ and $23.3 \%$; respectively).

Table 4 shows that security personnel were alone in more than one-third of WPV events. In addition, more than two-fifths and more than one-third of violent events occurred during evening shifts and official vacation other than Friday, respectively. More than one-fifth of violent events were reported to the hospital administration. Only $3.8 \%$ of perpetrators received a verbal warning from the directors and only $2 \%$ of 553 reported events resulted in a lawsuit against the perpetrator.

Table 5 shows that participants reported that the commonest effect of violence was being bothered $(80.9 \%)$, being fearful $(69.5 \%)$, and having work dissatisfaction (61.8\%) and anger/ anxiety (47.3\%). The commonest coping mechanisms were reporting to directors/supervisors $(94.7 \%)$, telling family/friends (92.4\%), pretending the event did not occur $(77.1 \%)$ and replying to perpetrators themselves at the time of the event (74.0\%).

\section{Discussion}

Hospital security workers, who are trained to offer tertiary prevention on escalation of an event, have also been acknowledged as a group at an increased risk of being assaulted ${ }^{12,16}$ and in need of tools to identify, alleviate, and avoid violent events in hospitals ${ }^{17}$.

In this study, the majority $(87.3 \%)$ of security personnel reported exposure to violence in the past year. A similarly high prevalence $(63.8 \%)$ of type II violence, which is perpetrated by a client receiving services from an organization, such as a patient or guest, was reported among security guards and police officers in a study of six US hospitals ${ }^{16}$. This high prevalence could be attributed to the nature of the work of security personnel, who repeatedly interfere in efforts to protect both staff and patient safety and are frequently injured in occurrences with violent patients ${ }^{18}$. It has been previously acknowledged that hospital safety and security employees are often ignored in the healthcare violence-related injury literature ${ }^{9}$. There are relatively few studies involving hospital security workers and these have revealed that these employees have some of the highest

\begin{tabular}{|c|c|}
\hline & n (\%) \\
\hline $\begin{array}{l}\text { Violence type } \\
\text { Physical } \\
\text { Pushing } \\
\text { Beating } \\
\text { Throwing objects } \\
\text { Spitting } \\
\text { Scratching } \\
\text { Attack with sharp weapon (stick, knife,cutter, scissors) } \\
\text { Attack with sticks/furniture } \\
\text { Pinching } \\
\text { Slapping } \\
\text { Kicking } \\
\text { Biting } \\
\text { Suffocation } \\
\text { Emotional (psychological) } \\
\text { Threat of physical force } \\
\text { Verbal abuse (name calling) } \\
\text { Sexual harassment/threat }\end{array}$ & $\begin{array}{l}137(24.8) \\
103(18.6) \\
68(12.3) \\
62(11.2) \\
45(8.1) \\
29(5.2) \\
27(4.9) \\
23(4.2) \\
16(2.9) \\
11(2.0) \\
8(1.4) \\
8(1.4) \\
131(23.7) \\
113(20.4) \\
9(1.6)\end{array}$ \\
\hline $\begin{array}{l}\text { Perpetrators } \\
\text { Patients' relatives/friends } \\
\text { Patients } \\
\text { Colleague } \\
\text { Hospital management }\end{array}$ & $\begin{array}{l}401(72.5) \\
129(23.3) \\
57(10.3) \\
5(0.9)\end{array}$ \\
\hline
\end{tabular}


Table 4. Circumstances, including time of event and to whom events are reported, of $\mathbf{5 5 3}$ workplace violence events reported by security personnel at a university hospital in Egypt.

\begin{tabular}{|c|c|}
\hline & n (\%) \\
\hline $\begin{array}{l}\text { Security personnel working alone at time } \\
\text { of event }\end{array}$ & $191(34.5)$ \\
\hline $\begin{array}{l}\text { Work shift at time of event } \\
\text { Morning shift (8am - 4pm) } \\
\text { Evening shift }(4-10 p m) \\
\text { Night shift (10pm - 8am) }\end{array}$ & $\begin{array}{l}106(19.2) \\
229(41.4) \\
198(35.8)\end{array}$ \\
\hline $\begin{array}{l}\text { Work day at time of event } \\
\text { Usual working days (Saturday to Thursday) } \\
\text { Weekly vacation (Friday) } \\
\text { Official vacations other than Friday }\end{array}$ & $\begin{array}{l}186(33.6) \\
176(31.5) \\
191(34.5)\end{array}$ \\
\hline $\begin{array}{l}\text { Event reporting } \\
\text { To hospital administration } \\
\text { To police } \\
\text { To Nursing Syndicate }\end{array}$ & $\begin{array}{l}121(21.9) \\
39(7.1) \\
26(4.7)\end{array}$ \\
\hline $\begin{array}{l}\text { Measures taken against perpetrators } \\
\text { Verbal warning from the directors } \\
\text { Lawsuit against the perpetrator }\end{array}$ & $\begin{array}{l}21(3.8) \\
11(2.0)\end{array}$ \\
\hline
\end{tabular}

Table 5. Consequences of workplace violence and coping mechanisms reported by reported by security personnel at a university hospital in Egypt in the past year $(n=131)$.

\begin{tabular}{|l|l|}
\hline & $\mathbf{n}(\%)$ \\
\hline Consequence & \\
Become bothered & $106(80.9)$ \\
Become fearful & $91(69.5)$ \\
Work dissatisfaction & $81(61.8)$ \\
Have anger/anxiety & $62(47.3)$ \\
Become irritable and watchful & $53(40.5)$ \\
Become suspicious & $49(37.4)$ \\
Decrease in performance and efficiency & $33(25.2)$ \\
Absence from work/request for sick leave & $32(24.4)$ \\
Lack of motivation & $28(21.4)$ \\
Feel chronic fatigue/pain & $19(14.5)$ \\
No effect & $19(14.5)$ \\
Feel ashamed/guilty & $13(9.9)$ \\
Plan to leave work/resign & $6(4.6)$ \\
\hline Coping mechanism & \\
Reported to director/supervisor & $124(94.7)$ \\
Told family/friends & $121(92.4)$ \\
\hline Pretended did not happen & $101(77.1)$ \\
Replied the perpetrators & $97(74.0)$ \\
Told a colleague & $68(51.9)$ \\
Try to forget the event & $35(26.7)$ \\
Transferred to other center/place of work & $19(14.5)$ \\
Defend self physically & $17(13.0)$ \\
No action & $13(9.9)$ \\
\hline
\end{tabular}

Categories are not mutually exclusive. rates of violence-related incidences within hospitals, anywhere from 2 to 5 times as many incidences as nurses ${ }^{10-12,19-21}$. However, almost no studies have been carried out to discuss the risk and protective factors for hospital security employees ${ }^{9}$.

In this study, being a woman and working for more than 5 years are independent predictors of violence exposure $(\mathrm{AOR}=7.7$ and 10.1; respectively). Several studies reported that younger and less experienced security officers have elevated rates of violence-related incidences ${ }^{8,12,22-25}$.

In contrast to these findings, a study conducted in the Midwest US, showed that both age and gender were not associated with verbal violence, although, while healthcare workers more than 60 years old were less exposed to physical violence (odds ratio $(\mathrm{OR})=0.31, \mathrm{p}<0.05)^{26}$. In another study of US hospitals, the higher prevalence of WPV across all sub-types in workers of a younger age suggested that younger workers are more prone to be victims ${ }^{16}$. Older workers may be more tolerant of these events resulting in their under reporting ${ }^{27}$ or they may be more skilful at event de-escalation.

Most studies that investigated gender of recipients of violencerelated incidences in healthcare reported that men are more liable to experience these injuries more than women ${ }^{11,12,23,28-30}$, while others have not found difference in rates based on victims' gender ${ }^{31,32}$.

The commonest suggestions to prevent violence in the current study were training $(73.3 \%)$ and assigning a larger number of personnel $(62.7 \%)$. The results of a survey of healthcare specialists from 19 hospitals in six cities of Heilongjiang Province, China are in agreement with our results, where the respondents exposed to WPV expected to obtain organizational and social support. Those exposed to psychological violence had a strong opinion of the need for targeted training to support their proficiency in responding to violence $(\mathrm{OR}=1.319,95 \% \mathrm{CI}$ : 1.034-1.658) and endorsing WPV legislation (OR $=1.968,95 \%$ CI: 1.523-2.543). Those exposed to physical violence incidences thought it might be helpful to strengthen staff with back-up support $(\mathrm{OR}=3.101,95 \% \mathrm{CI}: 1.085-8.860)^{33}$.

The commonest forms of physical violence in this study were pushing $(24.8 \%)$, beating $(18.6 \%)$ and throwing objects $(12.3 \%)$. The threat of physical force and verbal abuse were the commonest emotional violence experienced $(23.7 \%$ and 20.4\%; respectively). Patients' relatives/friends and patients themselves were the commonest perpetrators of violent events (72.5\% and 23.3\%; respectively). Similarly, verbal abuse $(32.8 \%)$ was the most prevalent subtype of type II violence among security guards and police officers in the US followed by physical threat $(24.1 \%)$, then finally physical assault $(6.9 \%)^{16}$.

Also, in the Emergency Department (ED) in Ankara, Turkey, regarding frequency of physical violence, security officers (75\%) described higher rates than other professions working in the ED $(\mathrm{p}<0.0001)$; exposure to any form of verbal abuse was 
highest among housekeepers (90.9\%) and security officers $(90.6 \%)$. In that study, self-reported verbal threat and sexual harassment among security officers was $75 \%$ and $15.6 \%$, respectively. Relatives or friends accompanying patients were most frequently responsible for the violence, and this confirms what was concluded in a previous study ${ }^{34}$.

In a study within a large hospital system in Midwest US, nurses $(\mathrm{OR}=1.87, \mathrm{p} \leq 0.01)$ and security personnel $(\mathrm{OR}=4.71$, $\mathrm{p} \leq 0.01$ ) reported verbal violent events in the past year more than any other job groups. Also, security staff $(\mathrm{OR}=30.79$, $\mathrm{p} \leq 0.001)$, registered nurses $(\mathrm{OR}=2.72, \mathrm{p} \leq 0.05)$, and mental health specialists $(\mathrm{OR}=18.71, \mathrm{p} \leq 0.01)$ were at a higher risk for physical violence ${ }^{26}$. These findings concerning physical violence consolidate other previous studies that have documented security personnel, mental health specialists, and nurses as being at higher risk ${ }^{11,16}$.

In this study, security personnel were alone in more than one-third of events. Additionally, more than two-fifths and more than one-third of violent events occurred during evening shifts and official vacation other than Friday, respectively. More than one-fifth of violent events were reported to the hospital administration. Only $3.8 \%$ of perpetrator received a verbal warning from the directors and only $2 \%$ had a lawsuit against the perpetrator. In a study from Israel, security employees emphasized the contribution of the behaviour of physicians and nurses to the development of a violent incident, especially verbal interaction, and delayed response time. A previous study reported that clinical staff had a negative attitude towards security personnel and considered that calling them to situations is a contributing factor to the development of a violent episode, which can escalate the situation and should be avoided if not necessary ${ }^{2}$.

In the present study, the commonest effects of violence were being bothered $(80.9 \%)$, being fearful $(69.5 \%)$, and having work dissatisfaction (61.8\%) and anger/anxiety (47.3\%). The commonest coping mechanisms were reporting to directors/ supervisors $(94.7 \%)$, telling family/friends $(92.4 \%)$, pretending the event did not occur $(77.1 \%)$ and replying to perpetrators
(74.0\%). Similarly, the most commonly reported reaction of ED staff in Turkey was sadness for sexual harassment (86\%), physical assault $(82.9 \%)$ and verbal threats $(82 \%)$. The other reactions were anger for physical assault (83.8\%), disappointment for verbal threat $(79.3 \%)$ and disgust for physical assaults (69.3\%). However, the most common coping method was "Doing nothing and keeping silent" (37.2-59.5\%), followed by reporting to a manager $(56.8 \%)$ for physical assaults, but this method is the least commonly used among participants experiencing verbal abuse (35.8\%), verbal threat $(34.7 \%)$ and sexual harassment $(34.9 \%)^{34}$.

\section{Limitations}

As this is a small-scale study in a single hospital, its results cannot be generalized to all health facilities. The possibility of overestimating the problem by security personnel to gain sympathy or more incentives cannot be excluded.

From the results of this study, we recommend that security personnel at university hospitals need more training, and more adequate numbers should be recruited to cover shifts and time points with high risk of violence. The feasibility of other countermeasures suggested by security personnel need to be tested in further intervention studies before being adopted. Routine notification, analysis and record keeping of WPV events should be mandatory to monitor changes in the magnitude of the problem.

\section{Data availability}

Underlying data

Harvard Dataverse: Workplace violence against security personnel at a university hospital in Egypt, https://doi.org/10.7910/ DVN/FRVSR2 ${ }^{35}$.

This project contains the following underlying data:

- Datasheet containing all variables obtained from the questionnaire for all participants.

Data are available under the terms of the Creative Commons Zero "No rights reserved" data waiver (CC0 1.0 Public domain dedication).
1. Stene J, Larson E, Levy M, et al.: Workplace violence in the emergency department: giving staff the tools and support to report. Perm J. 2015; 19(2): e113-7.

PubMed Abstract | Publisher Full Text | Free Full Text

2. Shafran-Tikva S, Chinitz D, Stern Z, et al:: Violence against physicians and nurses in a hospital: How does it happen? A mixed-methods study. Isr J Health Policy Res. 2017; 6(1): 59

PubMed Abstract | Publisher Full Text | Free Full Text

3. Kelloway EK, Barling JH, editors: In: Handbook of workplace violence. 1st ed. Sage Publications. 2006; 47-68. Reference Source

4. Phillips JP: Workplace Violence against Health Care Workers in the United States. N Engl J Med. 2016; 374(17): 1661-9.

PubMed Abstract | Publisher Full Text
5. Janocha JA, Smith RT: Workplace Safety and Health in the Health Care and Social Assistance Industry, 2003-07. US Bur Labor Stat. 2010; (2): 1-20. Reference Source

6. Taylor JL, Rew L: A systematic review of the literature: workplace violence in the emergency department. J Clin Nurs. 2011; 20(7-8): 1072-85. PubMed Abstract | Publisher Full Text

7. Hanson GC, Perrin NA, Moss $\mathrm{H}$, et al.: Workplace violence against homecare workers and its relationship with workers health outcomes: a cross-sectional study. BMC Public Health. 2015; 15(1): 11. PubMed Abstract | Publisher Full Text | Free Full Text

8. Kowalenko T, Walters BL, Khare RK, et al:: Workplace violence: a survey of emergency physicians in the state of Michigan. Ann Emerg Med. 2005; 46(2): 142-7. PubMed Abstract | Publisher Full Text 
9. Joshua J: Gramling. Protecting the Protectors: Violence-Related Injuries to Hospital Security Personnel and the Use of Conducted Electrical Weapons. In partial fulfillment of the requirements; for the degree of doctor of philosophy. University of minnesota. 2017.

Reference Source

10. Findorff MJ, McGovern PM, Wall MM, et al.: Reporting violence to a health care employer: a cross-sectional study. AAOHN J. 2005; 53(9): 399-406. PubMed Abstract

11. Arnetz JE, Aranyos D, Ager J, et al.: Development and application of a population-based system for workplace violence surveillance in hospitals. $A m$ $J$ Ind Med. 2011; 54(12): 925-34.

PubMed Abstract | Publisher Full Text

12. Pompeii L, Dement J, Schoenfisch A, et al.: Perpetrator, worker and workplace characteristics associated with patient and visitor perpetrated violence (Type II) on hospital workers: a review of the literature and existing occupational injury data. J Safety Res. 2013; 44: 57-64. PubMed Abstract | Publisher Full Text

13. Greene J: Patient safety versus workplace safety: Stun gun debate illustrates dueling federal mandates. Ann Emerg Med. 2011; 57(4): A20-3. Publisher Full Text

14. Bastianelli BT: TASERS in healthcare: myths and merits. $J$ Healthc Prot Manage. 2014; 30(1): 30-4. PubMed Abstract

15. El-Gilany AH, El-Wehady A, Amr M: Violence against primary health care workers in Al-Hassa, Saudi Arabia. J Interpers Violence. 2010; 25(4): 716-34. PubMed Abstract | Publisher Full Text

16. Pompeii LA, Schoenfisch AL, Lipscomb HJ, et al:: Physical assault, physical threat, and verbal abuse perpetrated against hospital workers by patients or visitors in six U.S. hospitals. Am J Ind Med. 2015; 58(11): 1194-204. PubMed Abstract | Publisher Full Text

17. Schoenfisch AL, Pompeii LA: Security Personnel Practices and Policies in U.S. Hospitals: Findings From a National Survey. Workplace Health Saf. 2016; 64(11): 531-542.

PubMed Abstract | Publisher Full Text

18. Arnetz JE, Hamblin L, Ager J, et al.: Application and implementation of the hazard risk matrix to identify hospital workplaces at risk for violence. Am J Ind Med. 2014; 57(11): 1276-84. PubMed Abstract | Publisher Full Text | Free Full Text

19. Sullivan C, Yuan C: Workplace assaults on minority health and mental health care workers in Los Angeles. Am J Public Health. 1995; 85(7): 1011-4. PubMed Abstract | Publisher Full Text | Free Full Text

20. Fernandes $\mathrm{CM}$, Bouthillette F, Raboud JM, et al.: Violence in the emergency department: a survey of health care workers. CMAJ. 1999; 161(10): 1245-8. PubMed Abstract | Free Full Text

21. Lehmann LS, McCormick RA, Kizer KW: A survey of assaultive behavior in Veterans Health Administration facilities. Psychiatr Serv. 1999; 50(3): 384-9. PubMed Abstract | Publisher Full Text

22. Bensley L, Nelson N, Kaufman J, et al.: Injuries due to assaults on psychiatric hospital employees in Washington State. Am J Ind Med. 1997; 31(1): 92-9. PubMed Abstract | Publisher Full Text

23. Gerberich SG, Church TR, McGovern PM, et al:: An epidemiological study of the magnitude and consequences of work related violence: the Minnesota Nurses' Study. Occup Environ Med. 2004; 61(6): 495-503.

PubMed Abstract | Publisher Full Text | Free Full Text

24. Privitera $\mathrm{M}$, Weisman $\mathrm{R}$, Cerulli $\mathrm{C}$, et al:: Violence toward mental health staff and safety in the work environment. Occup Med (Lond). 2005; 55(6): 480-6. PubMed Abstract | Publisher Full Text

25. Behnam M, Tillotson RD, Davis SM, et al.: Violence in the emergency department: a national survey of emergency medicine residents and attending physicians. J Emerg Med. 2011; 40(5): 565-79. PubMed Abstract | Publisher Full Text

26. Arnetz J, Hamblin LE, Sudan S, et al:: Organizational Determinants of Workplace Violence Against Hospital Workers. J Occup Environ Med. 2018; 60(8): 693-699.

PubMed Abstract | Publisher Full Text | Free Full Text

27. Whittington R, Shuttleworth S, Hill L: Violence to staff in a general hospital setting. J Adv Nurs. 1996; 24(2): 326-33. PubMed Abstract | Publisher Full Text

28. Camerino D, Estryn-Behar M, Conway PM, et al:: Work-related factors and violence among nursing staff in the European NEXT study: a longitudinal cohort study. Int J Nurs Stud. 2008; 45(1): 35-50.

PubMed Abstract | Publisher Full Text

29. Shields M, Wilkins K: Factors related to on-the-job abuse of nurses by patients. Health Rep. 2009; 20(2): 7-19. PubMed Abstract

30. Gacki-Smith J, Juarez AM, Boyett $L$, et al:: Violence against nurses working in US emergency departments. J Nurs Adm. 2009; 39(7-8): 340-9. PubMed Abstract | Publisher Full Text

31. Flannery RB Jr, Marks L, Laudani L, et al.: Psychiatric patient assault and staff victim gender: fifteen-year analysis of the Assaulted Staff Action Program (ASAP). Psychiatr Q. 2007; 78(2): 83-90. PubMed Abstract | Publisher Full Text

32. Kowalenko T, Gates D, Gillespie GL, et al:: Prospective study of violence against ED workers. Am J Emerg Med. 2013; 31(1): 197-205. PubMed Abstract | Publisher Full Text

33. Zhao S, Liu H, Ma H, et al.: Coping with Workplace Violence in Healthcare Settings: Social Support and Strategies. Int J Environ Res Public Health. 2015 12(11): 14429-44.

PubMed Abstract | Publisher Full Text | Free Full Text

34. Talas MS, Kocaöz S, Akgüç S: A survey of violence against staff working in the emergency department in ankara, Turkey. Asian Nurs Res (Korean Soc Nurs Sci). 2011; 5(4): 197-203.

PublMed Abstract | Publisher Full Text

35. Ahmed AA: Workplace violence against security personnel at a university hospital in Egypt. Harvard Dataverse, V1.2020.

http://www,doi.org/10.7910/DVN/FRVSR2 


\section{Open Peer Review}

\section{Current Peer Review Status:}

\section{Version 1}

Reviewer Report 14 July 2020

https://doi.org/10.5256/f1000research.25671.r65547

(C) 2020 Hegazy A. This is an open access peer review report distributed under the terms of the Creative Commons Attribution License, which permits unrestricted use, distribution, and reproduction in any medium, provided the original work is properly cited. The author(s) is/are employees of the US Government and therefore domestic copyright protection in USA does not apply to this work. The work may be protected under the copyright laws of other jurisdictions when used in those jurisdictions.

\section{Amal A. Hegazy}

${ }^{1}$ Department of Community Medicine, Faculty of Medicine, King Abdulaziz University, Jeddah, Saudi Arabia

2 Al-Azhar University, Cairo, Egypt

1. Security personnel are not considered one of the health care workers. The authors mentioned health care violence in the introduction, So, there is need to change.

2. The authors mentioned the response rate among the study group in the result section, it is better to transfer it to method section.

3. In logistic regression model, Kindly could the authors answer this question, what are the variables that entered in the model? In other words, did the authors make an association between the exposure and the outcome first, then he takes the significant one in the model or what did they do?

Is the work clearly and accurately presented and does it cite the current literature? Yes

Is the study design appropriate and is the work technically sound?

Yes

Are sufficient details of methods and analysis provided to allow replication by others? Yes

If applicable, is the statistical analysis and its interpretation appropriate? Yes

Are all the source data underlying the results available to ensure full reproducibility? 
Yes

Are the conclusions drawn adequately supported by the results?

Yes

Competing Interests: No competing interests were disclosed.

Reviewer Expertise: Occupational and environmental health topics

I confirm that I have read this submission and believe that I have an appropriate level of expertise to confirm that it is of an acceptable scientific standard.

Reviewer Report 29 May 2020

https://doi.org/10.5256/f1000research.25671.r63327

(C) 2020 Kabbash I. This is an open access peer review report distributed under the terms of the Creative Commons Attribution License, which permits unrestricted use, distribution, and reproduction in any medium, provided the original work is properly cited.

\section{Ibrahim Kabbash}

Public Health and Community Medicine, Faculty of Medicine, Tanta University, Tanta, Egypt

1. There is no need to mention the type of the study in the title.

2. The second paragraph in the introduction focused on health care violence. Security personnel can't be considered as health care workers. The topic is violence in a health care setting rather than violence among health care workers. This issue should be considered in the whole part of introduction.

3. The authors did no mention the response rate among participants and whether there was any refusal to participate.

4. What is the justification of categorization of participant by age at 35 years?

5. In table 4, event reporting to nursing syndicate is not logic and strange. It is logic to be reported to authority that can deal with the accident. What is the authority of nursing syndicates to deal with accidents occurring at the entrance of the hospital or the wards?

6. In table 5 how the exposed worker to violence feel guilty? I can understand he/she may feel ashamed but being guilty is not clear to me.

7. In discussion the authors repeated again most of figures mentioned in the results section. They should discuss information and not repeated results in discussion

Is the work clearly and accurately presented and does it cite the current literature? 
Yes

Is the study design appropriate and is the work technically sound?

Yes

Are sufficient details of methods and analysis provided to allow replication by others? Yes

If applicable, is the statistical analysis and its interpretation appropriate?

Yes

Are all the source data underlying the results available to ensure full reproducibility? Yes

Are the conclusions drawn adequately supported by the results?

Yes

Competing Interests: No competing interests were disclosed.

I confirm that I have read this submission and believe that I have an appropriate level of expertise to confirm that it is of an acceptable scientific standard.

The benefits of publishing with F1000Research:

- Your article is published within days, with no editorial bias

- You can publish traditional articles, null/negative results, case reports, data notes and more

- The peer review process is transparent and collaborative

- Your article is indexed in PubMed after passing peer review

- Dedicated customer support at every stage

For pre-submission enquiries, contact research@f1000.com

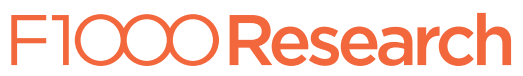

